\title{
TO ACCEPT OR REFUSE PATIENT'S GIFT IN MONEY? AND HOW? - CASE REPORT WITH REVIEW
}

\section{Vesna Kos}

\author{
Department of Family Medicine, University of Zagreb, Zagreb, Croatia
}

Corresponding Author: Vesna Kos, MD, MSc. Department of Family Medicine, University of Zagreb, 10000 Zagreb, Rockfellerova 4, Croatia; e-mail: vesnakos.dr@zg.t-com.hr

\begin{abstract}
This report describes a (rare) situation when a patient's first gift to a young doctor was in money. This happened in very specific circumstances - in a refugee camp during the War in Croatia. The data are taken from a large study on gifts, conducted on a representative sample of Croatian general practitioners (GPs), $\mathrm{N}=265$, from 2358 in total.

Pro and contra factors are discussed, considering tradition and customs, but also a lack of knowledge of young doctors in handling gifts in general. The intention of this report is primarily educative, with review of (scarce) literature, and recommendations, where the generally accepted rules might have exceptions.
\end{abstract}

Keywords: Gift Giving, Physician-Patient Relation, Financial Gift, Human Dignity, Cultural Background

\section{Introduction}

Although doctors "are among the most gifted people on planet Earth" [1], little is known about appropriate conduct in these situations, because literature about it is scanty $[2,3]$, and because most medical schools do not have this covered in their education programs. Consequently, young doctors are mostly unprepared for something they will be facing almost daily.

There are some general recommendations for receiving patients' gifts, and these are as follows: small gifts (as token of appreciation) are not ethically problematic, and are certainly more acceptable than big and expensive ones, gifts in nature are more acceptable then those in money, gifts after intervention better then those given beforehand [2-8]. And as the most important guideline: the intention (and not the value!) of the gift is valued; meaning: only gifts without open or hidden intention for some beneficence are acceptable $[2,4,5,8,9,10]$.

Furthermore, there are only sporadic articles in the official medical literature about receiving gifts $[2,3,8,11,12]$, and these are mostly based on single or hypothetical examples $[1,5$, $7,9,13]$, without a serious and consistent research on gifts. There are only few studies on patients' gifts, and these studies are small and made only on hospital doctors $[3,8,11,12]$.

Aiming to get a real (and not only hypothetical) insight into what happens during the process of receiving gifts, a study was conducted on a representative sample of Croatian GPs. A part of the study deals with the very first present in a doctor's career, with the descriptions of the doctor's and patient's reaction which both influenced the doctor-patient relationship, as a very important element in curing $[2-5,7,8,10-12]$.

The refusal of a gift in an improper manage might hurt patient (or his dignity) $[5,7$, $10,11,14,16,17]$, which is often overlooked in healthcare. Thus, the damage for the patient can by far exceed the value of the gift (because of long-term negative curing effects, based on the disturbed doctor-patient relation) $[2,4,5,7,10]$.

The aim is to show that it might be some specific situations in reality, regarding gifts, 
where the lack of knowledge is an obstacle, since an individual approach should be applied, regardless sometimes "obvious" and generally accepted recommendations $[2,3,7,10,14,16,17]$.

\section{Methods and examinees}

The survey, aimed to explore GPs' experiences concerning gifts, was conducted in 2006 on Croatian GPs and approved by the Ethical Committee of the Medical School of the University in Zagreb, approval number 380-59/11500-77/178.

The target population were all active GPs in Croatia, $\mathrm{N}=2358$. The sample was collected randomly as proportionally stratified, with the next stratum criteria: region (21 counties), gender, the number of patient in care (all visible from the List of Family Medicine Teams). The first participants were chosen as purposive sample and they formed the sample for pilot study. The GPs with less then two years of practice were excluded before giving them the oportunity to participate. Final $\mathrm{N}=265$, response rate $95.7 \%$.

The survey was originally designed in a form of a large questionnaire, to explore GPs' experiences concerning gifts, both those given to and those received from patients.

The first page aimed to describe the experience of the first patients' gift.

The questions on that page are as follows:
- (describe) What was your first gift (including time of study and internship)?

- At that time you were: student or intern or physician? If student, then write the year of study, if intern or physician write how many months.

- (describe) How did you react? Meaning: How did you feel?

- Did you say something and what was it? (write)

- How the patient did react? (describe)

The survey was conducted as an openended, led questionnaire, under supervision and with the presence of the same researcher. Questions were allowed during the survey, but the respondents were not permitted to agree among themselves about their responses, and no discussion with the researcher was allowed.

The oral and written instructions were clearly defined beforehand, and given immediately before the questionnaire was filled in. The survey respondents were pre-announced, but not the contents, only the theme.

\section{Results}

The data collected from the whole study show that Croatian physicians receive their first gift very early: $5.7 \%$ in their student days, $41.5 \%$ during internship, and $50.2 \%$ as young doctors, with a peak in the $1^{\text {st }}$ month of being a doctor.

The structure of the first gifts

SORTING GIFTS BY TYPE
\begin{tabular}{|l|c|c|}
\hline \multicolumn{1}{|c|}{ Type of gift } & Number & $\%$ \\
\hline coffee and/or sweets (standard gifts) & 161 & $60.8 \%$ \\
\hline food (mostly in rural practices) & 24 & $9.1 \%$ \\
\hline flowers & 19 & $7.2 \%$ \\
\hline drinks & 7 & $2.6 \%$ \\
\hline handmade products (embroidery) & 5 & $1.9 \%$ \\
\hline cosmetics & 5 & $1.9 \%$ \\
\hline money & 3 & $1.1 \%$ \\
\hline others (books, cigarettes, souvenirs) & 13 & $4.9 \%$ \\
\hline do not remember or left blank & 15 & $4.9 \%$ \\
\hline combined gifts & 265 & $100 \%$ \\
\hline \multicolumn{2}{|c|}{ TOTAL } & $5.7 \%$ \\
\hline Combinations include all types of gifts. \\
\hline Coffee and/or sweets are present in 14 combined gifts $=5.3 \%$, \\
\hline
\end{tabular}


Comment:

Most of the first gifts are symbolic and common (coffee and/or sweets in $66.1 \%$ ).

Only in three cases the first gift was in money, or partially in money (1.9\% in total).

\section{Description of the case wrote by the participant}

"I was an intern with about three months of practice. You wouldn't believe, but my first present was MONEY! It happened in a warrefugee camp. I was shocked and refused the gift. The patient was offended." (Author's translation)

\section{Discussion}

What can we see behind this short description by a doctor about refusing a monetary gift from a patient in a refugee camp?

At first glance the young physician was completely right: the patient was clearly poor. He might be rich "once upon a time", but not in the described situation: he was homeless, without any source of income, unemployed and without possibility to earn anything, without possibility to rear or cultivate something appropriate as a gift to the doctor from his own farm or garden. His only material possession was money, probably taken in a hurry while running away from his home. So, who would ever take anything from a man in such a bad lifesituation? The mere idea sounds horrible. According to the official recommendations, it was almost normal to refuse a gift: A) in money, [2$7,11,12], \mathrm{B})$ of a relatively big value regarding the circumstances $[2-8,11,12,18], \mathrm{C})$ from a poor patient $[2,4,5,7,14]$, i.e. from whom taking away the only value he had (i.e. money) would certainly diminish his already low property.

Yet, the next question is: why did this obviously poor patient offer a gift to the doctor? Why he tried to do it at all? The answer to this question is not so simple, and the right answer casts a very different light on the situation.

Refugees in the camp were mostly people from remote villages or provincial towns; they did not run away from metropolis like Zagreb. Customs are not the same in big cities as in villages, and local tradition might be very different $[4,5,7,8,14-17]$, thus should be considered $[4,5,7,14,15,17]$. In very remote places, people might have become accustomed over the centuries to the fact that there is no government or king to take care of them. Therefore, they appreciate help which is "here-andnow", not connecting it with "some far-off thing such as government", but only directly with the person who gives it. The doctor is the very one who helped, not the system, not state, not government [14].

$\Rightarrow$ "Me, as a patient, as a man given the help, I have to thank directly to doctor."

Furthermore, in the patient's mind, the healing is traditionally a kind of a gift. "Therefore, as a decent man I have to give another gift in return - because it is polite, and it is wrong not to say thanks, to oversee such a gift as healing, and not to give something in return. I don't want to become an indecent, dishonourable and dishonest man, this is about my dignity $[14,15,17] . "$

On the other hand, the young doctor studied and lived in a big city for many years, knowing the customs of a big city. Even if she might come from a provincial area, she forgot the village tradition and customs over the years. Most importantly, she had heard something about "inappropriate gifts in money" [2-4, 6, 11], but nobody in her medical school ever taught her the meaning of patients' gift and the behaviour in these situations. The sad fact is that gifts to doctors are much more discussed in daily papers than they are in competent and professional venues - by skilled teachers in medical schools. So, the young doctor could not see that this gift had no intention to any benefit, what is the key in distinction what gift is to be accepted vs. refused $[2,4,5,8,9,10]$.

\section{What should this young doctor do?}

The first rule is that the doctor must not hurt the patient. This is one of the basic principles regarding gifts from patients $[2,5,7,10$, 13, 17]. Yet, she did hurt him, she humiliated him and insulted his dignity (she wrote "he was offended").

Furthermore, the way the young doctor refused the gift disturbed the doctor-patient relationship. This relation is very important in curing process $[2,4,5,7,8,10-13,19]$, since disturbed physician-patient relation influence negatively on curing outcome. It is known that even just once disturbed relationship might 
diminish the curing effect forever [2, 5, 7], especially in family medicine $[5,7]$.

\section{Which would have been the} right choices for this young doctor?

1. She could have taken this "inopportune" gift, keeping in mind its value, and after some time give to this patient "occasionally" something of the similar value in return, like a gesture of favour, something that he really needed - and she "just happened to have".

2. She could have refused the gift, but in a very polite and careful manner $[2-5,7,10]$.

Just saying "no, thanks, I wouldn't take this" was not polite in this situation. This kind of refusal couldn't be polite to a man who had nothing to offer, nothing but his human dignity embodied in some money. Actually, she was embarrassed by the fact that a completely impoverished man offered her money. In such a situation the young doctor could not recognise the "love embodied in gift", as Stein described patients' gifts [18], as signs of gratitude and appreciation $[1,2,5,7,10]$. Overwhelmed by her own discomfort, as it often might happen $[3,5-7,8,11,12]$, she couldn't react appropriately and put the patient's best interest in the first place, as it is recommended [2, 4-6, 10, 13], and as sometimes suggested to be done against the own discomfort $[7,10]$.

She had to respect the only thing he had, his human dignity, and say for example:

"Oh, how nice and polite from you! I appreciate that, I see you are a good man. I promise you, we will have a coffee or lunch together the first day you leave this camp. We will celebrate this, and I'll be your guest. So, keep this money till this day, it will be so soon."

The patient would not see this as refusal, but rather as acceptance in some other and delayed way.

By making one of these choices she would not have offended the patient or hurt his dignity. Moreover, she would not break professional and her own rules, and she would not disturb the already well-established doctor-patient relationship [2, 4, 7, 10].

But, is it expected the doctor with three months of practice, and without any training on how to accept or politely refuse patients' gifts, to conduct this in such a fine way? Many authors agree this is not to be expected without proper education $[2,5-7,15]$.

\section{Conclusion}

1. There might be exceptions in avoiding monetary gifts, contrary to the general recommendation about accepting gifts in nature rather than those in money, because "there is nevertheless general consensus on what constitutes acceptable versus nonacceptable behavior" [2].

2 . The general rule about not hurting the patient should be at the first place when receiving patients' gifts.

3 . The local tradition and customs should be taken in consideration in these situations.

4. A doctor should recognise what is very important for a particular patient; for example: the high need of human dignity - even in certain extreme circumstances.

It seems that medical students need an adequate education about patients' gifts $[1,2$, $5-7,15]$, to develop appropriate and professsional conduct in the future.

\section{REFERENCES}

1. Enright WG, Miyamoto RT. Building a cathedral for your soul: generosity as a virtue and a practice. Otolaryngol Head Neck Surg. 2008 May; 138(5): 552-6.

2. Lyckholm LJ. Should physicians accept gifts from patients? JAMA. 1998; 280(22): 1944-6.

3. Spence SA. Patients bearing gifts: are there strings attached? BMJ. 2005; 331(7531): 1527-9.

4. Snyder L, Leffler C; Ethics and Human Rights Committee, American College of Physicians. Ethics manual: fifth edition. Ann Intern Med. 2005; 142(7): 560-82. Comments: Ann Intern Med. 2005; 143(8): 618. Ann Intern Med. 2008; 148(11): 887-8.

5. Gaufberg EH. Alarm and altruism: professional boundaries and the medical student. Clinical Teacher. 2006; 3: 206-9.

6. Oak JC. Accepting vendor gifts. Consider both legal and ethical factors before accepting or giving gifts. Healthc Exec. 2005; 20(4): 32-3.

7. Gaufberg E. Should physicians accept gifts from patients? Am Fam Physician. 2007; 76(3): 437-8.

8. Capozzi JD, Rhodes R. Gifts from patients. J Bone Joint Surg Am. 2004; 86A: 2339-40.

9. Andereck W. Point-counterpoint: should physicians accept gifts from their patients? Yes: If they are given out of beneficence or appreciation. West $\mathrm{J}$ Med. 2001 Aug; 175(2): 76. 
10. Brendel DH, Chu J, Radden J, Leeper H, Pope HG, Samson J, et al. The price of a gift: an approach to receiving gifts from patients in psychiatric practice. Harv Rev Psychiatry. 2007; 15(2): 43-51.

11. Drew J, Stoeckle JD, Billings JA. Tips, status and sacrifice: gift giving in the doctor-patient relationship. Soc Sci Med. 1983; 17(7): 399-404.

12. Levene M, Sireling L. Gift giving to hospital doctors-in the mouth of the gift horse. Br Med J. 1980; 281: 1685 .

13. Niselle P. Danger zone. When boundaries are crossed in the doctor-patient relationship. Aust Fam Physician. 2000; 29(6): 541-4.

14. Belli P, Gotsadze G, Shahriari H. Out-of-pocket and informal payments in health sector: evidence from Georgia. Health Policy. 2004; 70(1): 109-23.

15. Abbasi YI, Gadit AA. Accepting gifts from patients: how ethical can this be in the local context? J Pak Med Assoc. 2008; 58(5): 281-2.

16. Cockfort A, Andersson N, Paredes-Solís S, Caldwell $\mathrm{D}$, Mitchell S, Milne D, et al. An inter-country comparison of unofficial payments: results of a health sector social audit in the Baltic States. BMC Health Serv Res. 2008; 8: 15.

17. Takayama JI. Giving and receiving gifts: one perspective. West J Med. 2001 Aug; 175(2): 138-9.

18. Stein H. The gift in therapy. Am J Psychother. 1965; 19: 480-8.

19. Krones T, Richter G. Physicians' responsibility: doctor-patient relationship. Bundesgesundheitsblatt Gesundheitsforschung Gesundheitsschutz. 2008 Aug; 51(8): 818-26.
Резиме

\section{ДА СЕ ЗЕМЕ ИЛИ ДА СЕ ОДБИЕ ПАРИЧЕН ПОДАРОК ОД ПАЦИЕНТ? \\ И КАКО? - \\ ПРИКАЗ НА СЛУЧАЈ СО ПРЕГЛЕД}

\section{Весна Кос}

Оддел за семејна медицина, Универзитет во Загреб, Загреб, Хрватска

Се опишува (ретка) ситуација кога прв подарок во кариерата на млад лекар биле пари. Тоа се случило во многу специфична ситуација: во кампот за бегалци за време на Татковинската војна во Хрватска. Податоците се одбрани од голема студија за подароци, спроведена на општите лекари во Хрватска, $\mathrm{N}=265$, од вкупно 2.358.

$\mathrm{Ce}$ дискутираат причините за и против, земајќи ги предвид традицијата и обичаите, но, исто така, и неупатеноста на младите лекари во правилното професионално однесување при примањето подароци, генерално. Целта на овој извештај е првенствено едукативна, со преглед на (скудна) литература и препораки, при што може да има исклучоци од општите правила.

Клучни зборови: давање подароци, однос лекар пациент, паричен подарок, човечко достоинство, културно потекло 